\title{
Nicotine exposure affects mother's and pup's nutritional, biochemical, and hormonal profiles during lactation in rats
}

\author{
E Oliveira ${ }^{1}$, C R Pinheiro ${ }^{1}$, A P Santos-Silva ${ }^{1}$, I H Trevenzoli ${ }^{1}$, Y Abreu-Villaça ${ }^{1}$, J F Nogueira Neto ${ }^{1,2}$, \\ A M Reis ${ }^{3}$, M C F Passos ${ }^{1,4}$, E G Moura ${ }^{1}$ and P C Lisboa ${ }^{1}$ \\ ${ }^{1}$ Department of Physiological Sciences, Roberto Alcantara Gomes Biology Institute and ${ }^{2}$ Laboratory of Lipids, School of Medicine, State University of Rio de \\ Janeiro, Rio de Janeiro 20551-030, Brazil \\ ${ }^{3}$ Department of Physiology and Biophysics, Federal University of Minas Gerais, Belo Horizonte, Minas Gerais 31270-901, Brazil \\ ${ }^{4}$ Department of Applied Nutrition, Nutrition Institute, State University of Rio de Janeiro, Rio de Janeiro 20551-030, Brazil \\ (Correspondence should be addressed to P C Lisboa; Email: pclisboa@uerj.br)
}

\begin{abstract}
We have shown that maternal nicotine exposure during lactation has long-lasting effects on body adiposity and hormonal status of rat offspring. Here, we studied the nutritional and hormonal profiles in this experimental model. Two days after birth, osmotic minipumps were implanted in lactating rats divided into two groups: NIC continuous s.c. infusions of nicotine $(6 \mathrm{mg} / \mathrm{kg}$ per day) for 14 days and $\mathrm{C}-$ saline. Dams and pups were killed at 15 and 21 days of lactation. Body weight and food intake were evaluated. Milk, blood, visceral fat, carcass, and adrenal gland were collected. All the significant data were $P<0 \cdot 05$. At the end of nicotine exposure (15 days), dams presented higher milk production, hyperprolactinemia, and higher serum highdensity lipoprotein cholesterol (HDL-C). Milk from NIC
\end{abstract}

dams had higher lactose concentration and energy content. After nicotine withdrawal (21 days), dams showed lower food intake and hyperleptinemia. The 15-day-old NIC pups presented higher total body fat, higher HDL-C, serum leptin, serum corticosterone, and adrenal catecholamine content, but lower tyrosine hydroxylase protein levels. The 21-day-old NIC pups had higher body protein content and serum globulin. Thus, maternal nicotine exposure during lactation results in important changes in nutritional, biochemical, and hormonal parameters in dams and offspring. The pattern of these effects is clearly distinct when comparing the nicotineexposed group to the withdrawal group, which could be important for the programming effects observed previously. Journal of Endocrinology (2010) 205, 159-170

\section{Introduction}

It is well known that tobacco contains numerous compounds that are potentially cytotoxic, such as nicotine, thiocyanate, carcinogens, carbon, and certain gases (Stellman \& Djordjevic 2009). Tobacco smoke affects numerous biological processes including the secretion of hormones, such as ADH, GH, ACTH, cortisol, catecholamines, and leptin (Robinson 1977, Yeh \& Barbieri 1989, Grassi et al. 1994, Walker et al. 1999). In normal men, smoking causes an increase in heart rate and blood pressure as a result of blood vessel constriction (Kapoor $\&$ Jones 2005). Nicotine, an important addictive compound of tobacco smoke, is an exogenous acetylcholine agonist that activates nicotine receptors, including those in the adrenal medulla (Wakade \& Wakade 1983). After smoking, plasma levels of adrenaline and noradrenaline rise (Grassi et al. 1994, Walker et al. 1999, Reselandn et al. 2005); these factors play an important role in the development of hypertension.

During pregnancy, cigarette smoke is considered a risk factor for low birth weight and neurological abnormalities
(Butler \& Goldstein 1973, Navarro et al. 1989, DiFranza \& Lew 1995). In humans, smoking during pregnancy is related to lower leptin concentration in the cord blood of newborns (Mantzoros et al. 1997). Maternal smoking also causes an increase in the levels of catecholamines in the amniotic fluid, suggesting that fetal adrenergic activation results from fetal hypoxia and/or from a direct effect of nicotine on the fetal adrenergic system (Divers et al. 1981). Research has also shown an increased risk of hypertension in children whose mothers smoked during pregnancy (Blake et al. 2000).

While it has been established that many women quit smoking during pregnancy (Giglia et al. 2006, Polańska et al. 2006), little is known about postpartum maintenance of smoking cessation and relapse. Some studies reveal that most women who stop smoking during gestation relapse during lactation (McBride \& Pirie 1990, O'Campo et al. 1992, Hannöver et al. 2008). Lactation is a critical period of life once important cognitive and neurological developments occur. Mother's milk represents the primary source of nutrition (Golding et al. 1997). Nicotine is transferred 
through maternal milk and causes tachycardia in the offspring due to higher adrenergic activity. Cotinine, the main metabolite of nicotine, can be measured in blood, urine, saliva, and milk (Luck \& Nau 1987, Dahlstrom et al. 1990, Nel \& Morgan 1996, Narayanan et al. 2002). Recently, it has been demonstrated that tobacco smoke alters cytokine levels in maternal milk. Smoking mothers present lower IL-1 in the colostrum than non-smoking mothers (Zanardo et al. 2005). Because nicotine is present in the breast milk, it can affect other milk cytokines, such as leptin.

We recently showed that in rats, maternal nicotine exposure during lactation only leads to long-term effects on body weight (BW) regulation, leptin concentration, and thyroid function in adult offspring (Oliveira et al. 2009). In this study, we used nicotine osmotic minipumps at an infusion rate of $6 \mathrm{mg} / \mathrm{kg}$ per day in the mothers to produce nicotine levels quite similar to those achieved in heavy smokers (Murrin et al. 1987, Lichtensteiger et al. 1988). To our knowledge, there are a few experimental studies focusing on the effects of nicotine exposure exclusively during the early postnatal period. This may be of particular interest because there is a high rate of smoking relapse among lactating women (McBride \& Pirie 1990), and tobacco has wellknown effects on metabolic diseases and cardiovascular dysfunction. Thus, our aim was to evaluate the short-term consequences of maternal nicotine exposure, during lactation only, on the hormonal, biochemical, and nutritional profiles of mothers and suckling pups during nicotine exposure and after its withdrawal.

\section{Materials and Methods}

The use of the animals according to our experimental design was approved by the Animal Care and Use Committee of the Biology Institute of the State University of Rio de Janeiro (CEA/189/2007 and CEA/015/2009) that based its analysis on the principles adopted and promulgated by the Brazilian Law (Law no. 11.794/2008). Experiments were conducted to minimize the number of animals and the suffering caused by the procedures following the ethical doctrine of the three ' $\mathrm{Rs}$ ' - reduction, refinement, and replacement (Drummond 2009, Marques et al. 2009). Wistar rats were kept in a temperaturecontrolled room $\left(25 \pm 1^{\circ} \mathrm{C}\right)$ with artificial light-darkness cycles (lights on at $0700 \mathrm{~h}$ and lights off at $1900 \mathrm{~h}$ ). Three-monthold, virgin female rats were caged with male rats at the ratio of 3:1. After mating, each female was placed in an individual cage with free access to water and food until delivery.

\section{Model of neonatal nicotine exposure}

Two days after birth, 20 lactating rats were randomly assigned to one of the following groups:

Nicotine (NIC, $n=10$ ) - dams were lightly anesthetized with thiopental, a $3 \times 6 \mathrm{~cm}$ area on the back was shaved; and an incision was made to permit s.c. insertion of osmotic minipumps (Alzet, 2ML2, Los Angeles, CA, USA). To avoid the adverse effects of nicotine peaks, we chose to perform the nicotine exposure using s.c. osmotic minipump infusion. Pumps were prepared with nicotine-free base diluted in a saline solution $(\mathrm{NaCl} 0 \cdot 9 \%)$ to deliver an initial dose rate of $6 \mathrm{mg} / \mathrm{kg}$ of nicotine per day (during 14 days of lactation) as described previously (Abreu-Villaca et al. 2004). At this rate, this paradigm produces plasma nicotine levels similar to those in typical smokers, $\sim 25 \mathrm{ng} / \mathrm{ml}$ (Lichtensteiger et al. 1988). The incision was closed, and the mothers were permitted to recover in their home cages.

Control (C, $n=10)$ - dams were implanted with osmotic minipumps containing only saline solution, released for the same period as in rats in the experimental group.

At birth, litter adjustment was performed, and six male pups were kept per NIC or C dam to maximize lactation performance. During all lactation periods, BW (mothers and pups) and relative food intake (g/100 g BW) of the mothers were monitored daily. Dams and offspring were killed at 15 (end of NIC exposure) and 21 (6 days post NIC withdrawal) days of lactation by rapid decapitation, with no prior anesthesia, because anesthesia affects hormone and lipid metabolism. Blood, visceral fat mass (VFM), carcass, and adrenal gland were collected.

\section{Milk collection}

Milk samples were collected at 15 and 21 days of lactation. For this, dams were separated from litters for a period of $2 \mathrm{~h}$ before milking (Bonomo et al. 2005). After i.p. injection of oxytocin (5 UI) under pentobarbital anesthesia $(30 \mathrm{mg} / \mathrm{kg}$ $\mathrm{BW})$, milk was manually collected from all teats. We obtained $0.5-1.0 \mathrm{ml}$ from each lactating rat, and the samples were frozen at $-20{ }^{\circ} \mathrm{C}$ for further analysis.

\section{Estimation of milk production}

This experiment was performed as described previously (Bonomo et al. 2005). Briefly, NIC and C pups were divided into two subgroups: a) breast-feeding or b) fasting, and the pups were separated from the dams for $24 \mathrm{~h}$ and used as controls to estimate milk production. Both groups were weighed before (W1) and after $24 \mathrm{~h}$ (W2), and milk production was estimated according to the formula: Milk yield $(\mathrm{g} /$ day $)=\mathrm{W} 2 \mathrm{a}-\mathrm{W} 1 \mathrm{a}(1-K)$, where the correction factor $K$ is the relative loss of weight in the fasted pups $(K=\mathrm{W} 1 \mathrm{~b}-\mathrm{W} 2 \mathrm{~b} / \mathrm{W} 1 \mathrm{~b})$.

\section{Detection of cotinine in serum and milk}

Serum and milk cotinine levels were determined at 15 days of lactation using a cotinine assay kit obtained from Orasure Technologies (Bethlehem, PA, USA) in accordance with the manufacturer's recommendations. Dams were separated from 
their litters, and $2 \mathrm{~h}$ later, milk was collected as described previously. After that, dams and pups were killed for blood collection. Samples were stored at $-20{ }^{\circ} \mathrm{C}$ until analysis.

\section{Analysis of milk biochemical composition}

Total milk protein was measured according to the Peterson method (1977), using BSA as the standard. Protein concentration was determined based on the Stauffer formula (1975), and the results were expressed in $\mathrm{mg} / \mathrm{ml}$.

Total lipids were measured in milk samples diluted in distilled water $(1: 25)$ by colorimetric assay, using a Bioclin commercial kit. Results were expressed in $\mathrm{mg} / \mathrm{dl}$.

Milk lactose was measured by a colorimetric method using picric acid (Khramov et al. 2008), using commercial lactose as the standard (Sigma). Results were expressed in $\mathrm{mg} / \mathrm{ml}$.

Milk energy was calculated from milk production in $24 \mathrm{~h}$ using the isolated macronutrients.

\section{Body composition evaluation}

On the day of killing, VFM was excised (mesenteric, epididymal, and retroperitoneal white adipose tissue) and immediately weighed for evaluation of central adiposity (Toste et al. 2006). Total body fat and protein levels were determined by carcass analysis (Fagundes et al. 2007). Pups were eviscerated; the carcasses were weighed, autoclaved for $1 \mathrm{~h}$, and homogenized in distilled water (1:1). Homogenates were stored at $4{ }^{\circ} \mathrm{C}$ for analysis.

Three grams of homogenate were used to gravimetrically determine fat content. Samples were hydrolyzed in a shaking water bath at $70{ }^{\circ} \mathrm{C}$ for $2 \mathrm{~h}$ with $30 \% \mathrm{KOH}$ and ethanol. Total fatty acids and free cholesterol were removed with three successive washes of petroleum ether. After drying overnight in vacuum, tubes were weighed and data were expressed as grams of fat per $100 \mathrm{~g}$ of carcass.

Protein content was determined in $1 \mathrm{~g}$ of homogenate. Tubes were centrifuged at $2000 \mathrm{~g}$ for $10 \mathrm{~min}$. The total protein concentrations were determined by the Lowry method (Lowry et al. 1951). Data were expressed as grams of protein per $100 \mathrm{~g}$ of carcass.

\section{Serum biochemical evaluation}

Total cholesterol (TC), triglycerides, high-density lipoprotein cholesterol (HDL-C), and low-density lipoprotein cholesterol (LDL-C) were analyzed using Biosystem commercial test kits with an automated A15 spectrophotometer (Biosystems S.A., Barcelona, Spain). LDL-C and very lowdensity lipoprotein cholesterol (VLDL-C) were calculated according to the Friedewald equation (Friedewald et al. 1972):

VLDL-C $=$ triglycerides $/ 5$

LDL-C $=(\mathrm{TC}-\mathrm{HDL}-\mathrm{C}-$ triglycerides $) / 5$
Castelli indices I and II, which correlate to atherogenesis, were obtained using the formulas:

1) Castelli index I = Total cholesterol/HDL-C

2) Castelli index II = LDL-C/HDL-C.

The Biuret reaction (Gornall et al. 1949) was performed for total serum protein measurement, and absorbance of products was determined on a spectrophotometer (automated A15 BioSystems analyzer). Serum albumin was determined by bromocresol green method (Doumas et al. 1971), and globulin fraction was measured as the difference between total protein and albumin. Values were expressed as $\mathrm{mg} / \mathrm{dl}$.

\section{Hormone determination by RIA}

Blood samples were centrifuged $\left(1500 \mathrm{~g} / 20 \mathrm{~min}\right.$ per $\left.4{ }^{\circ} \mathrm{C}\right)$ to obtain sera, which were kept at $-20^{\circ} \mathrm{C}$ until the assay. All measurements were performed in one assay.

Serum prolactin (PRL) concentrations were measured by a specific RIA using reagents supplied by the National Institute of Diabetes and Digestive and Kidney Diseases (NIH, Bethesda, MD, USA). Data were reported in nanogram from the reference preparation RP-3 with an assay sensitivity of $0.3 \mathrm{ng} / \mathrm{ml}$ and an intra-assay coefficient of $8 \%$.

Serum and milk leptin concentrations were measured by a specific RIA kit (Linco Research, Inc., St Louis, MO, USA) that measures both rat and mouse leptin (range of detection: $0 \cdot 5-50 \mathrm{ng} / \mathrm{ml}$; intra-assay variation $2 \cdot 9 \%$ ).

Serum corticosterone was measured using a specific commercial RIA kit (ICN Biomedicals Inc., Aurora, OH, USA) with an assay sensitivity of $50 \mathrm{ng} / \mathrm{ml}$ and an intra-assay coefficient of variation of $7 \%$.

\section{Catecholamine level quantification}

Adrenal glands were used for the quantification of total catecholamines (epinephrine and norepinephrine) using the trihydroxyindole fluorescence method (Trevenzoli et al. 2007). Left adrenal glands were homogenized in $500 \mu \mathrm{l}$ of $10 \%$ acetic acid and centrifuged $(10000 \boldsymbol{g}$ for $1 \mathrm{~min})$. For the assay, $50 \mu \mathrm{l}$ of the supernatant/epinephrine standards were mixed with $250 \mu \mathrm{l}$ of phosphate buffer $(0 \cdot 5 \mathrm{M}, \mathrm{pH} 7 \cdot 0)$ and $25 \mu$ of potassium ferricyanate $(0 \cdot 5 \%)$ followed by incubation (20 min; ice bath). The reaction was stopped with $500 \mu \mathrm{l}$ ascorbic acid/10 M NaOH (1:19). The parameters used in the fluorimeter (Victor2, PerkinElmer, Waltham, MA, USA) were $420 \mathrm{~nm}$ excitation and $510 \mathrm{~nm}$ emission. Results were obtained by plotting the values as a linear regression of the standard epinephrine curve. Data were expressed as micrometer catecholamines.

\section{Western blotting analysis}

In order to evaluate adrenal function on the last day of nicotine exposure when adrenal catecholamine levels were high, tyrosine hydroxylase (TH) levels in the adrenal medulla were 
quantified by western blotting. TH, an essential enzyme in the catecholamine synthesis pathway, was measured in 15-day-old pups. For this, adrenal glands were processed for western blotting as reported previously (Trevenzoli et al. 2007, Fagundes et al. 2009). Briefly, glands were homogenized in $1 \mathrm{ml}$ phosphate buffer $(\mathrm{pH} 7 \cdot 4)$, containing $1 \mu \mathrm{l}$ protease inhibitor cocktail $(1 \mathrm{mg} / \mathrm{ml}$ each of aprotinin, leupeptin, and trypsin inhibitor), and centrifuged at $1120 \mathrm{~g}$ for $5 \mathrm{~min}$ at $4{ }^{\circ} \mathrm{C}$. Protein concentration in the supernatants was determined using the Pierce BCA Protein Assay Kit (Thermo Scientific, San Jose, CA, USA). The supernatants were analyzed by SDSPAGE using $10 \mu \mathrm{g}$ total protein. Samples were electroblotted onto nitrocellulose membranes (Hybond P ECL membrane, Amersham Biosciences). Membranes were incubated with Tris-buffered saline (TBS) containing 5\% non-fat dry milk for 90 min to block non-specific binding sites. Then, membranes were washed with TBS and incubated with a specific primary antibody (monoclonal mouse anti-TH; Sigma-Aldrich) overnight at $4{ }^{\circ} \mathrm{C}$ (diluted 1:2000 in $0.5 \%$ non-fat dry milkcontaining TBS). Anti-actin (I19 sc, goat polyclonal 1616; Santa Cruz Biotechnology, Inc., Santa Cruz, CA, USA) at a 1:500 dilution was used as the internal control. Membranes were washed and incubated with secondary antibody (goat anti-mouse; Santa Cruz Biotechnology) conjugated with HRP (diluted 1:2000 in $0.5 \%$ non-fat dry milk-containing TBS) for $1 \mathrm{~h}$ at room temperature. Finally, TH bands were visualized by chemiluminescence (Kit ECL plus, Amersham Biosciences) followed by exposure to autoradiographic film (Hyperfilm ECL, Amersham Biosciences) for $5 \mathrm{~s}$. Area and density of the bands were quantified by Image $\mathrm{J}$ software (Media Cybernetics, Bethesda, MD, USA). Results were expressed as relative (\%) to the control group.

\section{Statistical analysis}

Results were reported as mean \pm s.E.M. GraphPad Prism 5 was used for statistical analyses and graphics (GraphPad Software, Inc., La Jolla, CA, USA). Changes in BW and food intake were analyzed by two-way ANOVA and Newman-Keuls multiple comparison tests. TH expression was analyzed by the non-parametric Mann-Whitney $U$ test. The other experimental data were analyzed by unpaired Student's $t$-test with significance level set at $P<0 \cdot 05$. We studied two offspring from each mother at each time point (ten pups per group). However, for the analyses, litter was used as the experimental unit so we considered the average of values from animals of the same litter instead of using individual animal values.

\section{Results}

\section{Cotinine levels}

Cotinine levels of control dams and pups were below the technique's detection limit $(<8 \mathrm{ng} / \mathrm{ml})$. Nicotine treatment during 14 days of lactation affected cotinine milk and serum levels. In NIC-treated dams, milk and serum levels of cotinine
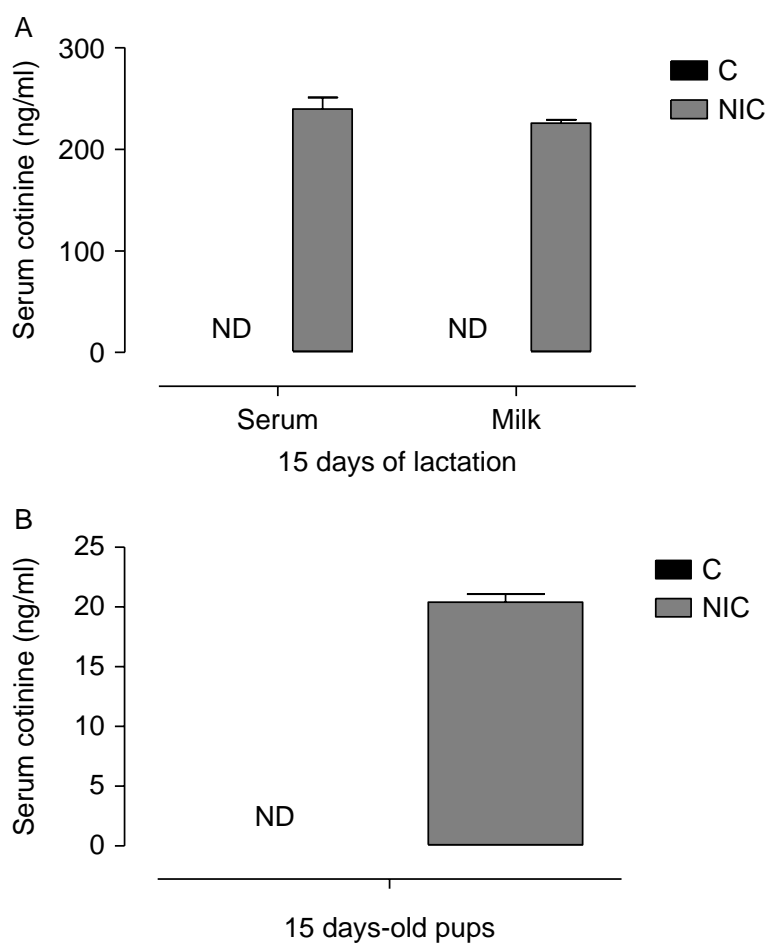

Figure 1 Milk and serum cotinine in NIC-treated (NIC) or salinetreated $(\mathrm{C})$ lactating rats at 15 days of lactation (A). Serum cotinine in NIC or C pups (B). Note that nicotine metabolic levels are non-detectable (ND) in control dams and pups. Values represent mean \pm S.E.M. of five to ten rats per group.

were similar (Fig. 1A). The 15-day-old NIC pups presented lower serum cotinine (Fig. 1B) compared with maternal levels, probably as a result of separation from their mothers before killing.

\section{Mothers}

During nicotine exposure, NIC dams exhibited no change in $\mathrm{BW}$ or food intake in comparison to the $\mathrm{C}$ group (Fig. 2). However, NIC dams showed lower food intake during the last 3 days of lactation (day 19: $-19 \%$, day 20: $-22 \%$, and day 21: $-36 \%$; Fig. 2 A, $P<0 \cdot 05)$. At weaning, NIC dams showed higher serum and milk leptin levels $(+68 \%$ and +3 times respectively, Fig. $3 \mathrm{~A}$ and $\mathrm{B}, P<0 \cdot 05)$.

At 15 days of lactation, NIC dams showed higher serum PRL $(+60 \%$, Fig. $4, P<0 \cdot 05)$ as well as higher milk production and energy $(+45$ and $+36 \%$ respectively, Table $1, P<0 \cdot 05)$. Analysis of milk biochemistry showed that NIC dams had higher lactose content $(+29 \%$, Table 1 , $P<0 \cdot 05$ ) only at 15 days of lactation, with no changes in milk protein or lipids during either of the periods studied.

As shown in Table 2, we observed higher levels of HDL-C $(+16 \%, P<0 \cdot 05)$ and lower Castelli index I values $(-9 \%$, $P<0.05)$ in NIC dams at 15 days of lactation. At weaning, no alterations in serum biochemical parameters were detected in NIC dams. 

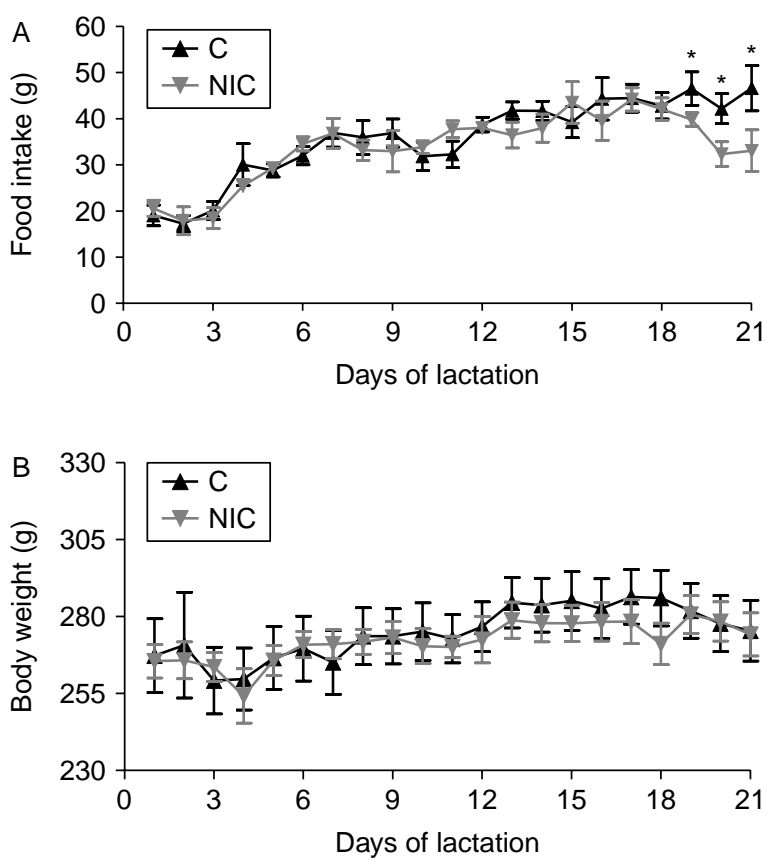

Figure 2 Food intake (A) and body weight (B) in NIC-treated (NIC) or saline-treated $(\mathrm{C})$ lactating rats during lactation. Values represent mean \pm s.E.M. of five dams per group. ${ }^{*} P<0 \cdot 05$ versus $C$.

NIC dams presented no change in serum corticosterone (Fig. 5A), adrenal total catecholamine content (Fig. 5B), or adrenal gland mass (data not shown) during both lactation periods.

\section{Progeny}

Maternal NIC exposure did not alter BW gain in offspring during lactation (Fig. 6A). We observed hyperleptinemia $(+35 \%, P<0 \cdot 05)$ in 15 -day-old NIC pups, as depicted in Fig. 6B.

As shown in Table 3, the 15-day-old NIC pups showed higher total fat mass $(+30 \%, P<0 \cdot 05)$ and a trend toward a significant increase for VFM $(+73 \%, P=0 \cdot 08)$. At weaning, these pups presented only higher total body protein $(+33 \%$, $P<0 \cdot 05)$.

Fifteen-day-old NIC pups presented higher serum HDL-C $(+24 \%$; Table 2, $P<0 \cdot 05)$, but this difference was not maintained at weaning. At weaning, this group showed higher serum globulin $(+34 \%, P<0 \cdot 05)$.

Serum corticosterone levels were higher in 15-day-old NIC pups compared with the control group (Fig. 7A). Adrenal catecholamine content $(+69 \%$, Fig. $7 \mathrm{~B}, P<0 \cdot 05)$ as well as adrenal gland mass (C: $2 \cdot 50 \pm 0 \cdot 17$, NIC: $3.49 \pm 0.20 \mathrm{mg}, P<0 \cdot 05)$ was higher in 15 -day-old NIC pups, but these parameters were unchanged at weaning. Adrenal TH protein expression was lower $(-33 \%, P<0 \cdot 05)$ in NIC pups at the end of the period of maternal exposure to nicotine (Fig. 8).

\section{Discussion}

There is a high rate of smoking relapse among women who quit smoking during pregnancy (McBride \& Pirie 1990, O'Campo et al. 1992, Hannöver et al. 2008). Nonetheless, most epidemiological and experimental studies on maternal smoking or nicotine exposure were performed during pregnancy or pregnancy and lactation. In the present study, for the first time, we used an experimental model of postnatal nicotine treatment to show that maternal nicotine exposure during lactation leads to important changes in the nutritional, biochemical, and hormonal profiles in both mother and offspring. After nicotine withdrawal, some alterations revert to baseline, despite the emergence of other metabolic changes. Accordingly, we have identified lactation as a period that is sensitive to the isolated effects of nicotine. Future studies are necessary to verify whether similar alterations occur in smoking mothers and lactating neonates. Developmental differences occur in rats when compared with humans. Some structures that are immature in rats at birth mature only in postnatal period (in the first week of life), whilst in humans,
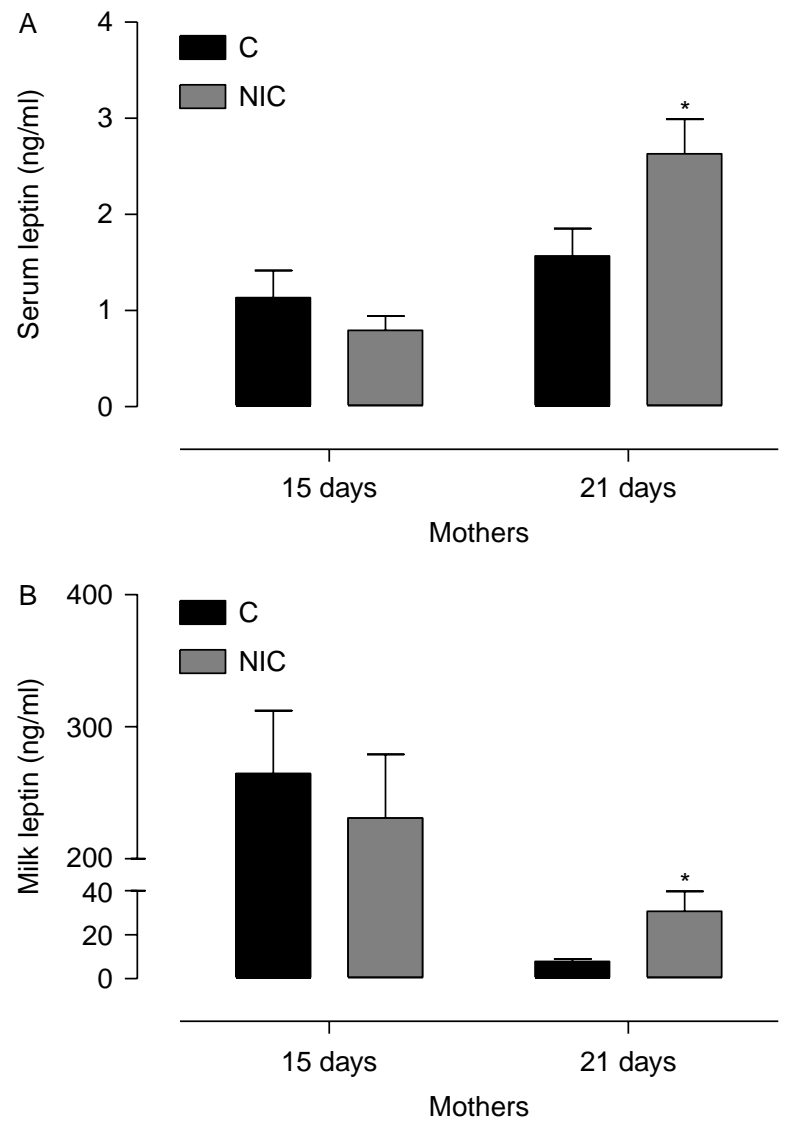

Figure 3 Serum (A) and milk (B) leptin content in NIC-treated (NIC) or saline-treated (C) lactating rats at 15 and 21 days of lactation. Values represent mean \pm S.E.M. of five dams per group. ${ }^{*} P<0.05$ versus $\mathrm{C}$. 


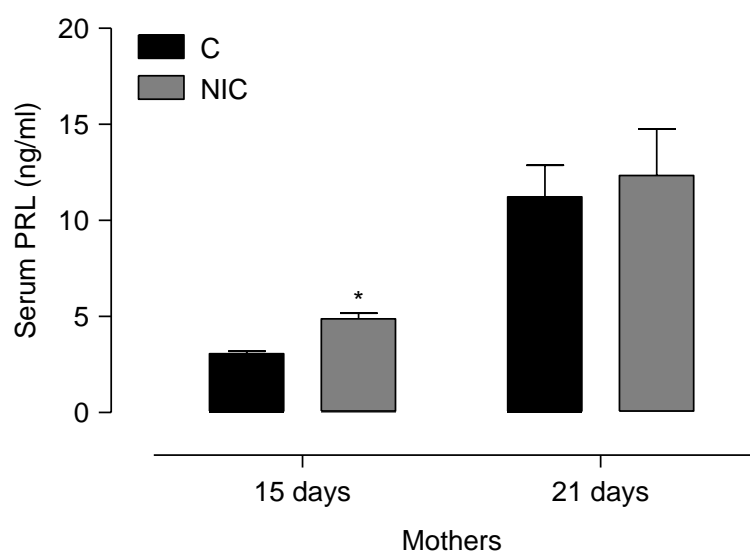

Figure 4 Serum PRL in NIC-treated (NIC) or saline-treated (C) lactating rats at 15 and 21 days of lactation. Values represent mean \pm S.E.M. of five dams per group. ${ }^{*} P<0 \cdot 05$ versus $C$.

this happens in gestation. Lactation in rats is a critical period to nicotine exposure, corresponding roughly, at least concerning to the neural development to the second trimester of gestation in humans (Vinay et al. 2005).

\section{Changes in lactating mothers}

The goal of this study was to characterize the effect of nicotine alone during lactation, which is the main cigarette compound that is addictive. We believe that this could represent the maternal smoking effect upon the progeny. Serum nicotine levels of $25 \mathrm{ng} / \mathrm{ml}$ are characteristic of heavy smokers (Lichtensteiger et al. 1988). To simulate this situation during lactation, lactating rats were implanted with s.c. osmotic minipumps releasing $6 \mathrm{mg} / \mathrm{kg}$ per day nicotine continuously (Oliveira et al. 2009). The serum nicotine:cotinine ratio was $1: 5$ to $1: 10$ (Trauth et al. 2000). In the present study, we detected high levels of serum cotinine in NIC dams $(239 \mathrm{ng} / \mathrm{ml})$ as well as in the milk $(226 \mathrm{ng} / \mathrm{ml})$. Then, in our experimental model, NIC dams were exposed to nicotine at levels that mimicked those in mothers who smoke heavily. Regarding the pups, maternal treatment with nicotine resulted in very low cotinine levels $(20 \cdot 4 \mathrm{ng} / \mathrm{ml})$. Because nicotine is transferred through the milk (Narayanan et al. 2002), separation of the pups from their mothers for $2 \mathrm{~h}$ to obtain milk samples before killing may have led to underestimations of the real impact of maternal nicotine exposure.

Adult rats treated with nicotine lose weight and are hypophagic (Li et al. 2000); however, treatment with nicotine during pregnancy does not affect maternal BW gain or food intake (Chen et al. 2005). In our study, lactating rats had no change in BW and food intake during nicotine exposure. Both pregnancy and lactation period are peculiar in several aspects. Particularly during lactation, many mechanisms are activated in order to supply the high energy requirement, including hyperphagia, basal metabolic rate reduction, and preferential nutrient flux for lactogenesis (Dewey 1998). Accordingly, it is possible that during this particular period, these events gain importance and counterbalance the wellknown effects of nicotine in non-lactating animals. However, after nicotine withdrawal, lactating dams displayed lower food intake. The hyperleptinemia in NIC dams observed at weaning could be responsible for this lower food intake. The high leptin levels in the milk of NIC dams at weaning may be due to the higher levels of leptin in maternal serum.

At the end of nicotine exposure (15 days of lactation), dams showed higher serum PRL that corresponded to higher levels of milk production. In fact, previous studies showed that smoking acutely increases plasma PRL (Wilkins et al. 1982, Gossain et al. 1986). At weaning, in the absence of nicotine, these parameters were normalized. Again, only under the effects of nicotine, we detected changes in milk composition, i.e. higher lactose content. This alteration may be responsible for the higher energy contained in the milk of NIC dams at 15 days of lactation. Also, PRL is orexigenic during lactation (Roy et al. 2007). Thus, PRL can be the counterbalancing factor that normalizes food intake due to the probable anorexigenic effect mediated by nicotine.

Cigarette smoking contributes to cardiovascular disease through alterations in the lipid profile, and in particular, the impact on HDL-C, because smoking cessation leads to an increase in HDL-C (Oeser et al. 1999, Maeda et al. 2003). Mixed results have been reported for nicotine replacement therapy (chewing gum, patches, and nasal spray). Certain studies described an increase in HDL-C concentrations (Allen et al. 1994), while other studies showed no lipoprotein

Table 1 Milk changes in NIC-treated dams during lactation. Values represent mean \pm S.E.M. of five lactating rats per group

\begin{tabular}{|c|c|c|c|c|}
\hline & \multicolumn{2}{|c|}{ 15th lactation day } & \multicolumn{2}{|c|}{ 21st lactation day } \\
\hline \multicolumn{5}{|l|}{ Milk nutrients } \\
\hline Lactose $(\mathrm{mg} / \mathrm{ml})$ & $27 \cdot 02 \pm 3 \cdot 01$ & $38 \cdot 31 \pm 3 \cdot 13^{a}$ & $23 \cdot 78 \pm 2 \cdot 55$ & $28 \cdot 93 \pm 3 \cdot 10$ \\
\hline Milk total protein $(\mathrm{mg} / \mathrm{ml})$ & $72 \cdot 42 \pm 4 \cdot 10$ & $64 \cdot 11 \pm 8 \cdot 12$ & $63 \cdot 10 \pm 4 \cdot 78$ & $66 \cdot 76 \pm 3 \cdot 26$ \\
\hline Cholesterol $(\mathrm{mg} / \mathrm{dl})$ & $320 \cdot 4 \pm 15 \cdot 86$ & $369 \cdot 2 \pm 24 \cdot 11$ & $383 \cdot 0 \pm 30 \cdot 21$ & $379 \cdot 0 \pm 35 \cdot 85$ \\
\hline
\end{tabular}

\footnotetext{
${ }^{\text {a }}$ Significant differences between groups.
} 
Table 2 Serum biochemical parameters in NIC-treated dams and offspring during lactation. Values represent mean \pm s.E.M. of five to ten dams per group. For pups, the average of values from animals of the same litter was used so that $n=5$ per group

\begin{tabular}{|c|c|c|c|c|}
\hline & \multicolumn{2}{|c|}{15 days } & \multicolumn{2}{|c|}{21 days } \\
\hline & $\mathrm{C}$ & $\mathrm{NIC}$ & $\mathrm{C}$ & NIC \\
\hline \multicolumn{5}{|l|}{ Mothers } \\
\hline Total cholesterol (mg/dl) & $71 \cdot 20 \pm 3 \cdot 16$ & $74 \cdot 90 \pm 2 \cdot 56$ & $55 \cdot 60 \pm 4 \cdot 48$ & $58 \cdot 30 \pm 4 \cdot 12$ \\
\hline HDL-C (mg/dl) & $27 \cdot 60 \pm 1 \cdot 03$ & $32 \cdot 00 \pm 1 \cdot 07^{*}$ & $21 \cdot 11 \pm 2 \cdot 7$ & $22 \cdot 67 \pm 4 \cdot 7$ \\
\hline LDL-C (mg/dl) & $25 \cdot 40 \pm 3 \cdot 20$ & $28 \cdot 00 \pm 3 \cdot 03$ & $27 \cdot 29 \pm 6 \cdot 30$ & $23 \cdot 60 \pm 4 \cdot 47$ \\
\hline VLDL-C (mg/dl) & $18 \cdot 20 \pm 2 \cdot 31$ & $14 \cdot 90 \pm 2 \cdot 37$ & $16 \cdot 90 \pm 2 \cdot 17$ & $13 \cdot 80 \pm 1 \cdot 90$ \\
\hline Triglycerides (mg/dl) & $90 \cdot 30 \pm 11 \cdot 53$ & $75 \cdot 20 \pm 11 \cdot 83$ & $84 \cdot 60 \pm 10 \cdot 89$ & $69 \cdot 40 \pm 9 \cdot 52$ \\
\hline Castelli index I & $2 \cdot 58 \pm 0 \cdot 07$ & $2 \cdot 35 \pm 0 \cdot 06^{*}$ & $3 \cdot 41 \pm 0 \cdot 58$ & $3 \cdot 89 \pm 0 \cdot 67$ \\
\hline Castelli index II & $0 \cdot 93 \pm 0 \cdot 12$ & $0 \cdot 87 \pm 0 \cdot 09$ & $1 \cdot 84 \pm 0 \cdot 61$ & $1 \cdot 71 \pm 0 \cdot 45$ \\
\hline Total protein $(\mathrm{mg} / \mathrm{dl})$ & $6 \cdot 11 \pm 0 \cdot 09$ & $6 \cdot 03 \pm 0 \cdot 07$ & $5 \cdot 76 \pm 0 \cdot 23$ & $5 \cdot 71 \pm 0 \cdot 24$ \\
\hline Albumin (mg/dl) & $2 \cdot 73 \pm 0 \cdot 24$ & $3 \cdot 16 \pm 0 \cdot 26$ & $2 \cdot 33 \pm 0 \cdot 13$ & $2 \cdot 15 \pm 0 \cdot 17$ \\
\hline Globulin (mg/dl) & $3 \cdot 38 \pm 0 \cdot 23$ & $2 \cdot 87 \pm 0 \cdot 26$ & $3 \cdot 43 \pm 0 \cdot 13$ & $3 \cdot 56 \pm 0 \cdot 10$ \\
\hline \multicolumn{5}{|l|}{ Pups } \\
\hline Total cholesterol (mg/dl) & $146 \cdot 9 \pm 5 \cdot 36$ & $159 \cdot 6 \pm 6 \cdot 99$ & $104 \cdot 7 \pm 4 \cdot 12$ & $126 \cdot 7 \pm 7 \cdot 02$ \\
\hline HDL-C (mg/dl) & $28 \cdot 70 \pm 0 \cdot 92$ & $35 \cdot 70 \pm 1 \cdot 84 *$ & $30 \cdot 50 \pm 2 \cdot 73$ & $41 \cdot 70 \pm 3 \cdot 15$ \\
\hline LDL-C (mg/dl) & $91 \cdot 20 \pm 5 \cdot 94$ & $97 \cdot 20 \pm 8 \cdot 64$ & $52 \cdot 40 \pm 4 \cdot 66$ & $59 \cdot 10 \pm 5 \cdot 31$ \\
\hline VLDL-C (mg/dl) & $26 \cdot 88 \pm 3 \cdot 09$ & $26 \cdot 70 \pm 3 \cdot 35$ & $21 \cdot 80 \pm 3 \cdot 02$ & $25 \cdot 90 \pm 2 \cdot 53$ \\
\hline Triglycerides (mg/dl) & $134 \cdot 4 \pm 15 \cdot 38$ & $133 \cdot 7 \pm 16 \cdot 96$ & $109 \cdot 1 \pm 15 \cdot 12$ & $129 \cdot 7 \pm 12 \cdot 50$ \\
\hline Castelli index I & $5 \cdot 15 \pm 0 \cdot 21$ & $4 \cdot 55 \pm 0 \cdot 26$ & $3 \cdot 63 \pm 0 \cdot 29$ & $3 \cdot 125 \pm 0 \cdot 19$ \\
\hline Castelli index II & $3 \cdot 22 \pm 0 \cdot 24$ & $2 \cdot 78 \pm 0 \cdot 28$ & $1 \cdot 92 \pm 0.29$ & $1 \cdot 50 \pm 0 \cdot 19$ \\
\hline Total protein $(\mathrm{mg} / \mathrm{dl})$ & $4 \cdot 82 \pm 0 \cdot 12$ & $4.92 \pm 0.09$ & $5 \cdot 44 \pm 0 \cdot 19$ & $6 \cdot 14 \pm 0 \cdot 14$ \\
\hline Albumin $(\mathrm{mg} / \mathrm{dl})$ & $2 \cdot 34 \pm 0 \cdot 07$ & $2 \cdot 48 \pm 0 \cdot 10$ & $3 \cdot 02 \pm 0 \cdot 17$ & $2 \cdot 89 \pm 0 \cdot 08$ \\
\hline Globulin (mg/dl) & $2 \cdot 48 \pm 0 \cdot 10$ & $2 \cdot 44 \pm 0.09$ & $2 \cdot 42 \pm 0 \cdot 19$ & $3 \cdot 25 \pm 0 \cdot 23 *$ \\
\hline
\end{tabular}

HDL-C, high-density lipoprotein cholesterol; LDL-C, low-density lipoprotein cholesterol; VLDL-C, very low-density lipoprotein cholesterol. $* P<0 \cdot 05$.

increase until nicotine withdrawal (Quensel et al. 1989, Thomas et al. 1995). In adult female rats, nicotine treatment increases TC and non-esterified fatty acids (Abd el Mohsen et al. 1997). However, to date, there are no data concerning the short-term effect of maternal nicotine exposure during lactation upon serum lipid profile. In our study, for the first time, we found higher levels of HDL-C in NIC dams at the end of nicotine exposure, similar to the findings published by Allen et al. (1994). This result is interesting, and certainly deserves more study. We suggest that these higher levels result from a compensatory mechanism typical of the lactation period, which was not observed in non-lactating female rats. Moreover, our results suggest that the deleterious effect of smoking on HDL cannot be attributed to nicotine.

It is well known that nicotine and other cholinergic agonists act directly through nicotine receptors in chromaffin cells of the adrenal medulla, increasing catecholamine production and release (Sala et al. 2008). Furthermore, nicotine can stimulate the hypothalamic-pituitary-adrenal axis, increasing glucocorticoid levels (Pauly et al. 1992). Nonetheless, with regard to the evaluation of maternal adrenal hormones, we did not observe significant changes in the incidence of corticosteronemia or adrenal catecholamine content in lactating rats during treatment with nicotine or after its withdrawal. Our results signal that these mothers are not stressed in our experimental model of neonatal nicotine exposure.

\section{Changes in suckling pups}

In previous experimental studies, pre- and postnatal nicotine exposure failed to cause changes in BW during the exposure period (Chen \& Kelly 2005, Gao et al. 2005). As demonstrated previously by our group (Oliveira et al. 2009), maternal nicotine exposure did not affect BW gain of NIC offspring during lactation. Interestingly, pups showed higher fat mass during nicotine exposure, but after nicotine withdrawal, weaned pups did not display changes in adiposity. At 15 days, NIC pups showed hyperleptinemia that may have been caused by higher adiposity since this hormone is mainly produced by adipose tissue (Ahima 2005) or the result of higher leptin transfer through maternal milk.

At weaning, in the absence of nicotine, NIC pups displayed higher body protein content and elevated serum globulin. Because leptin stimulates GH secretion (Tannenbaum et al. 1998), it is possible that the high leptin levels of 15-day-old NIC pups stimulate muscle protein synthesis through $\mathrm{GH}$ action, resulting in higher levels of total body protein. Hyperleptinemia is also associated with higher protein content in the carcass (Toste et al. 2006). Also, some hormones, such as leptin, insulin, GH, sex steroids, and thyroid hormones, are capable of altering liver production of proteins such as globulin (Gómez 2007, Szymeczko et al. 2009). Maybe, the increase in serum globulin levels of NIC pups at weaning is a consequence of changes, such as hyperleptinemia. 

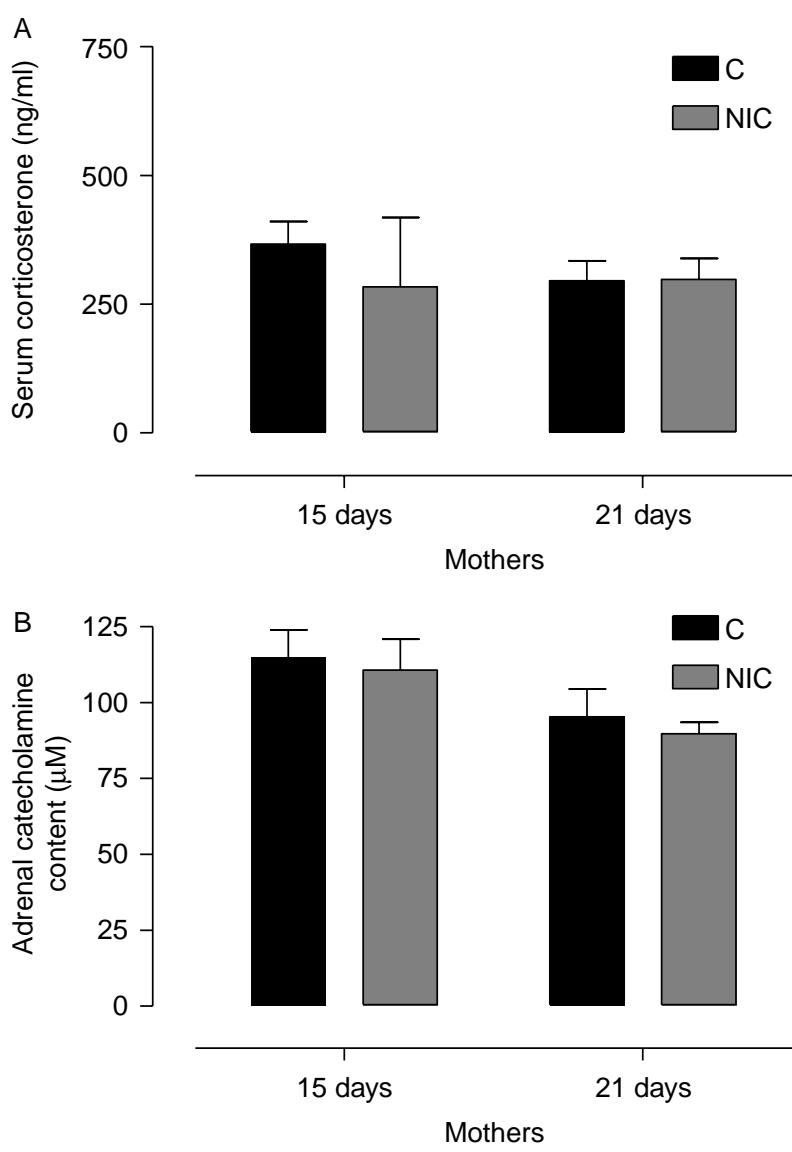

Figure 5 Serum corticosterone (A) and adrenal catecholamine content in NIC-treated (NIC) or saline-treated (C) lactating rats at 15 and 21 days of lactation. Values represent mean \pm s.E.M. of five dams per group.

As observed in mothers, we detected higher serum HDL-C in 15-day-old NIC pups. Therefore, as explained for the mothers, nicotine exposure during lactation could exert a protector effect against the development of dyslipidemia in offspring, despite the higher TC observed in weaned NIC pups.

Adrenal medulla stimulation occurs in smokers due to nicotine-stimulated catecholamine release (Aziz et al. 1978, Hansen et al. 1997). Maternal nicotine treatment for 14 days of lactation yielded higher adrenal gland mass and total catecholamine levels in 15-day-old pups; these changes may have resulted from a direct effect of nicotine on adrenal chromaffin cells (Sala et al. 2008). Notably, leptin stimulates catecholamine synthesis and secretion (Trevenzoli et al. 2007), so the present findings may be due to higher serum leptin in NIC pups.

On the other hand, we detected lower levels of adrenal TH protein, a key enzyme in the catecholamine synthesis pathway, in 15-day-old NIC pups. Thus, the observation of elevated catecholamine content in combination with lower $\mathrm{TH}$ expression in suckling pups at the end of nicotine exposure suggests that these neonates present dysfunctional catecholamine synthesis and reduced catecholamine secretion. It is also possible that the excess of catecholamines inhibits $\mathrm{TH}$ expression and activity as a mechanism for feedback control of the biosynthetic pathway (La Gamma \& Black 1989). However, we cannot rule out desensitization of the nicotine receptor induced by long-term exposure to nicotine. This phenomenon would explain lower $\mathrm{TH}$ expression as well as higher levels of catecholamines in association with lower levels of cholinergically stimulated release. In contrast, other studies have shown higher $\mathrm{TH}$ expression and activity in the adrenal medulla of rats exposed acutely (Tank et al. 1998, Sterling \& Tank 2001) or chronically to nicotine (Sun et al. 2003). Cheng et al. (2005) observed no changes in $T h$ mRNA levels in rats that were chronically exposed. Distinct outcomes may be related to the period of exposure. The present study is the only one in which exposure was restricted to the lactation period.

In weaned offspring whose mothers received nicotine from day 2 until day 14 of lactation, there were no changes in total catecholamine content, suggesting that after nicotine withdrawal, the alteration in adrenal medulla is normalized.
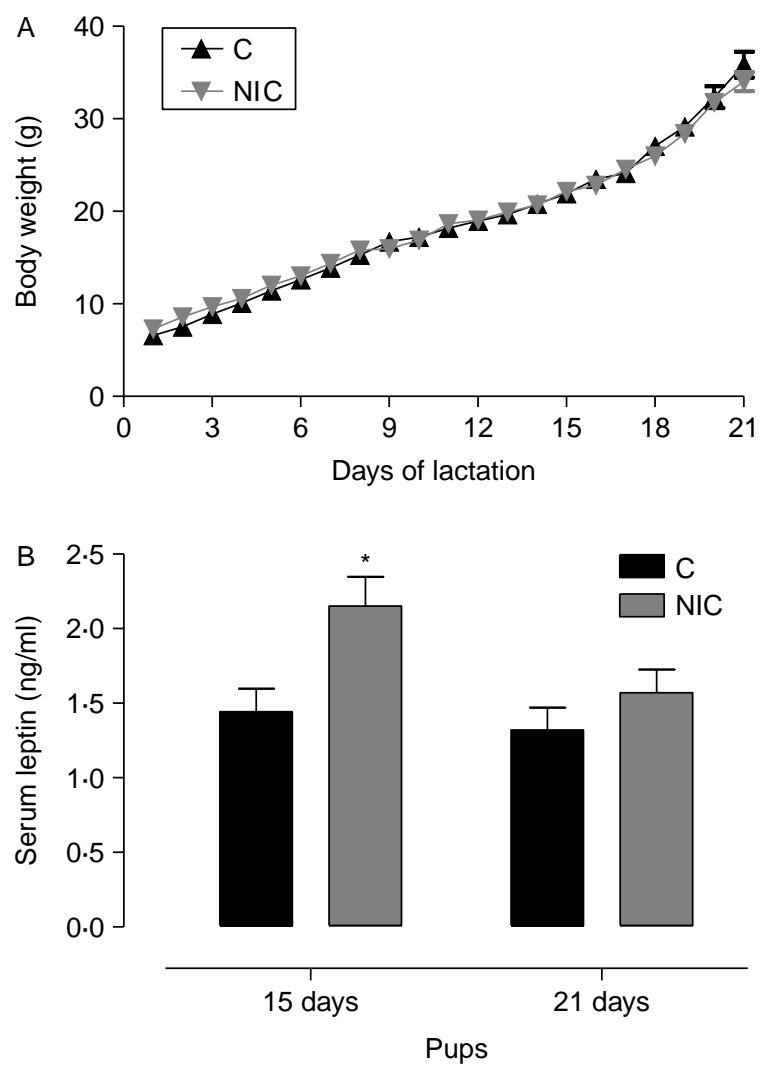

Figure 6 Body weight during lactation (A) and serum leptin (B) of pups whose mothers were nicotine $(\mathrm{NIC})$ or saline $(\mathrm{C})$ exposed during lactation. For body weight, values represent mean \pm S.E.M. of ten pups per group. For leptin, the average of values from animals of the same litter was used so that $n=5$ per group. ${ }^{*} P<0 \cdot 05$ versus $C$. 
Table 3 Body composition of pups from NIC-treated dams during lactation. Values represent mean \pm S.E.M. The average of values from animals of the same litter was used so that $n=5$ per group

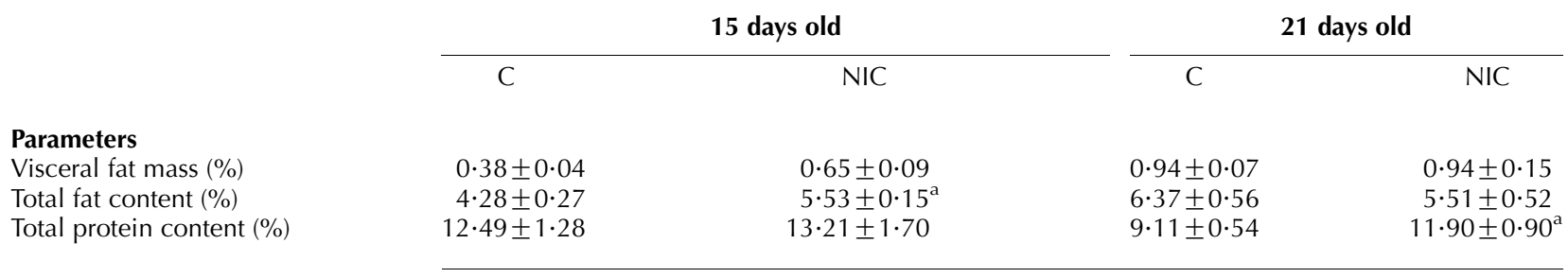

${ }^{\text {aS }}$ ignificant differences between groups.

We have already shown that maternal nicotine exposure causes early hypothyroidism during lactation. This effect is normalized at weaning when the animals are no longer under the influence of nicotine. However, at adulthood, these animals develop secondary thyroid hypofunction (Oliveira et al. 2009). Then, even with the normalization of catecholamine content at weaning, NIC offspring may present adrenal medullary dysfunction at adulthood, as that occurring for thyroid status.

Cigarette smoking acutely raises serum cortisol levels (Yeh \& Barbieri 1989), and nicotine increases ADH. These factors may cause higher ACTH and cortisol release (Robinson 1977). In our experimental model, serum corticosterone concentrations were higher in NIC pups at 15 days of lactation. It is well known that intra-adrenal portal vascular system provides the medulla with uniquely high concentrations of glucocorticoids. These high concentrations are needed to induce the medullary enzyme, phenylethanolamine-N-methyltransferase, which controls the synthesis of epinephrine from norepinephrine (Wurtman 2002). Then, the hypercorticosteronemia detected could be responsible for the elevated catecholamine production in NIC pups at the end of the period of maternal exposure to nicotine. Previously, in the model of neonatal hyperleptinemia, we also observed the association between higher serum corticosterone and higher adrenal total catecholamine contents in adult life (Fraga-Marques et al. 2009). Data on the relationship between nicotine and corticosterone are divergent; rats that are chronically nicotine treated may have higher serum corticosterone (Davis et al. 2005) or no alteration (Cruz et al. 2007). Chen et al. (2007) showed that during pregnancy, nicotine exposure leads to an increase in maternal corticosterone that results in higher corticosterone levels in the fetus. However, we did not observe changes in maternal corticosterone during nicotine exposure or after its removal. This may explain, at least in part, the lack of any alteration in the corticosteronemia observed in NIC pups at 21 days of lactation. We can therefore conclude that stress does not play a role in these events at weaning. On the other hand, as evidenced for thyroid function in a previous study (Oliveira et al. 2009) and already mentioned for catecholamine in the present data, even with the normalization of glucocorticoid levels at weaning, NIC offspring may present long-term consequences of stress mechanism.

\section{Final considerations}

In the present study, at least, there are three ways to understand the effects of nicotine. First, nicotine transfer through maternal milk (Dahlstrom et al. 1990, Narayanan et al. 2002) may change some factor(s) in offspring. Secondly, maternal alterations caused by nicotine treatment, for example nutritional and/or hormonal changes, may be transferred through the milk to the pups. Thirdly, our findings may result from functional changes in both mothers and pups.
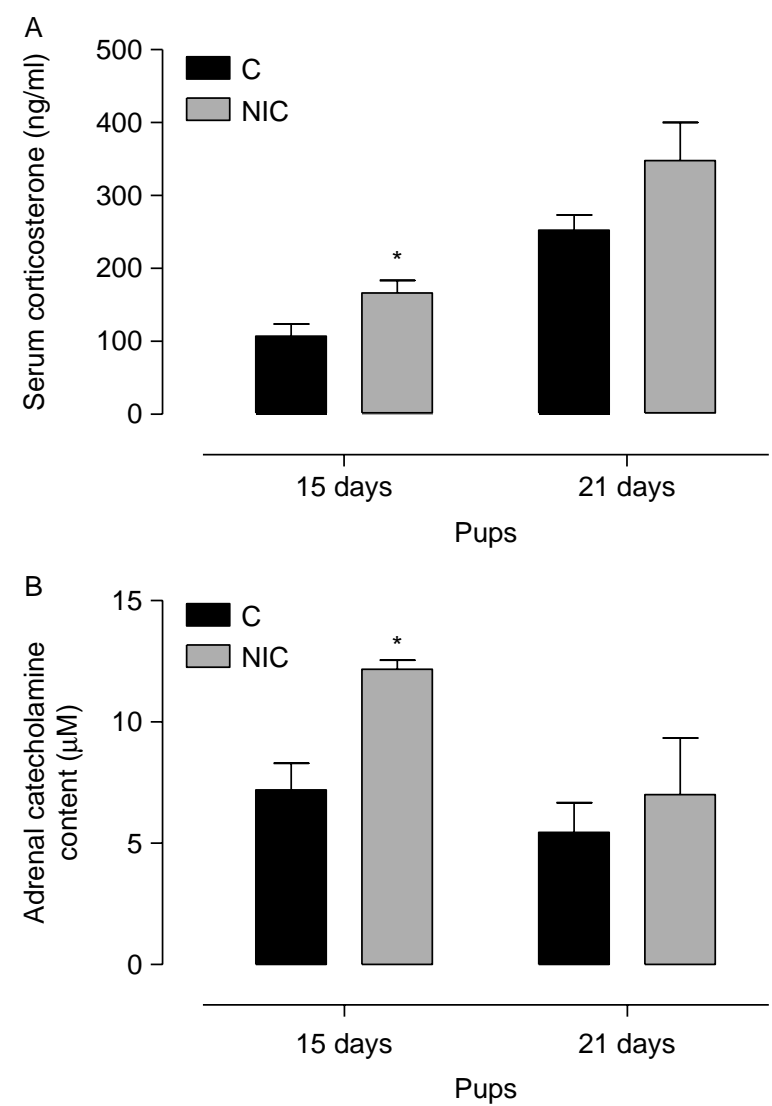

Figure 7 Serum corticosterone (A) and adrenal catecholamine content (B) of 15- and 21-day-old pups whose mothers were nicotine (NIC) or saline (C) exposed during lactation. Values represent mean \pm S.E.M. The average of values from animals of the same litter was used so that $n=5$ per group. ${ }^{*} P<0 \cdot 05$ versus $C$. 


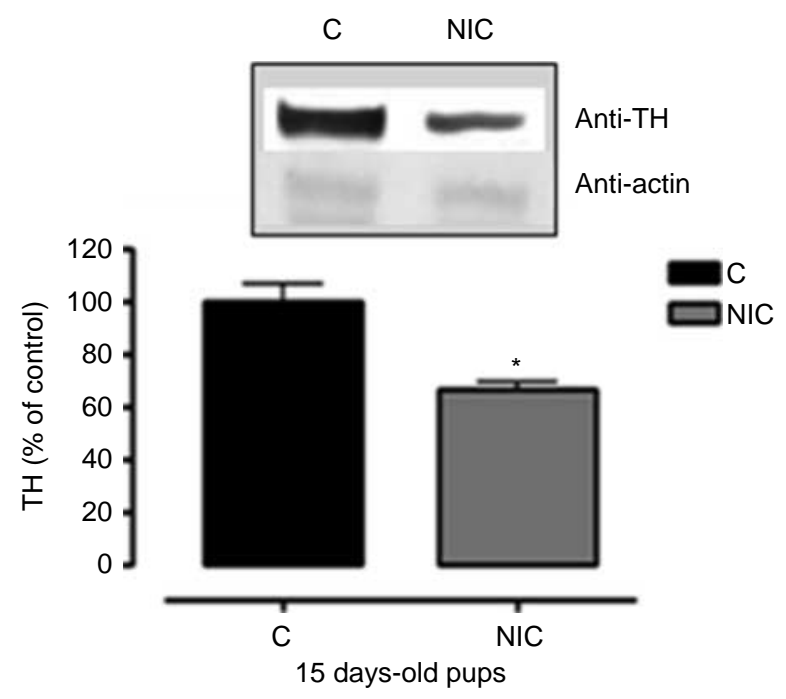

Figure 8 Tyrosine hydroxylase $(\mathrm{TH})$ content of 15 -day-old pups whose mothers were nicotine $(\mathrm{NIC})$ or saline $(\mathrm{C})$ exposed during lactation. Representative blots and density of protein were evaluated by western blotting method in adrenal medullae. Results were expressed as relative (\%) to the control group. Actin content was used as control loading. Values are expressed as mean \pm s.E.M. of ten pups per group. ${ }^{*} P<0 \cdot 05$.

In conclusion, we have demonstrated that maternal nicotine exposure exclusively during lactation induces changes in mothers, milk and pups. The patterns of these effects are clearly distinct during exposure compared with withdrawal. As epidemiological studies show that maternal tobacco smoke during gestation and lactation can lead to subsequent hypertension, it is possible that the transient early adrenal medullary dysfunction caused by nicotine exposure may have a later impact on cardiovascular parameters in adult progeny. Despite the fact that generalizations to the human population should be carried out with care due to inherent differences between species, our results indicate that exposure to nicotine during the lactation period involves deleterious nutritional, biochemical, and hormonal alterations in both mothers and neonates. Other tobacco components could also have an effect, and we are developing new experiments using the total cigarette smoke, with or without nicotine.

\section{Declaration of interest}

The authors declare that there is no conflict of interest that could be perceived as prejudicing the impartiality of the research reported.

\section{Funding}

This research was supported by the 'National Council for Scientific and Technological Development' (Conselho Nacional de Desenvolvimento Científico e Tecnológico - CNPq), the 'Carlos Chagas Filho Research
Foundation of the State of Rio de Janeiro' (Fundação Carlos Chagas Filho de Amparo à Pesquisa do Estado do Rio de Janeiro - FAPERJ), and Coordination for the Enhancement of Higher Education Personnel (Coordenação de Aperfeiçoamento de Pessoal de Nível Superior-CAPES).

\section{Acknowledgements}

All authors are grateful to Antonio CM de Sá, Vania Pinto, and Ana Maria B Coutinho from Laboratory of Lipids (LabLip, UERJ) for lipid profile determination. We also thank Mr Carlos Roberto, Miss Monica Moura, and Mr Luciano Santos for their technical assistance.

\section{References}

Abd el Mohsen MM, Fahim AT, Motawi TM \& Ismail NA 1997 Nicotine and stress: effect on sex hormones and lipid profile in female rats. Pharmacological Research 35 181-187.

Abreu-Villaca Y, Seidler FJ \& Slotkin TA 2004 Does prenatal nicotine exposure sensitize the brain to nicotine-induced neurotoxicity in adolescence? Neuropsychopharmacology 29 1440-1450.

Ahima RS 2005 Central actions of adipocyte hormones. Trends in Endocrinology and Metabolism 6 307-313.

Allen SS, Hatsukami D \& Gorsline J 1994 Cholesterol changes in smoking cessation using the transdermal nicotine system. Transdermal Nicotine Study Group. Preventive Medicine 23 190-196.

Aziz MT, Fahmy K \& El-Masry A 1978 Urinary catecholamines in habitual smokers and nonsmokers. Acta Physiologica Academiae Scientiarum Hungaricae 52 429-433.

Blake KV, Gurrin LC, Evans SF, Beilin LJ, Landau LI, Stanley FJ \& Newnham JP 2000 Maternal cigarette smoking during pregnancy, low birth weight and subsequent blood pressure in early childhood. Early Human Development 57 137-147.

Bonomo IT, Lisboa PC, Passos MC, Pazos-Moura CC, Reis AM \& Moura EG 2005 Prolactin inhibition in lactating rats changes leptin transfer through the milk. Hormone and Metabolic Research 37 220-225.

Butler NR \& Goldstein H 1973 Smoking in pregnancy and subsequent child development. BMJ 8 573-575.

Chen WJ \& Kelly RB 2005 Effect of prenatal or perinatal nicotine exposure on neonatal thyroid status and offspring growth in rats. Life Sciences $\mathbf{7 6}$ $1249-1258$.

Chen H, Vlahos R, Bozinovski S, Jones J, Anderson GP \& Morris MJ 2005 Effect of short-term cigarette smoke exposure on body weight, appetite and brain neuropeptide Y in mice. Neuropsychopharmacology 30 713-719.

Chen M, Wang T, Liao ZX, Pan XL, Feng YH \& Wang H 2007 Nicotineinduced prenatal overexposure to maternal glucocorticoid and intrauterine growth retardation in rat. Experimental and Toxicologic Pathology 59 245-251.

Cheng YS, Glazkova D, Serova L \& Sabban LE 2005 Effect of prolonged nicotine infusion on response of rat catecholamine biosynthetic enzymes to restraint and cold stress. Pharmacology, Biochemistry, and Behavior 82 559-568.

Cruz FC, DeLucia R \& Planeta CS 2007 Effects of chronic stress on nicotineinduced locomotor activity and corticosterone release in adult and adolescent rats. Addiction Biology 13 63-69.

Dahlstrom A, Lundell B, Curvall M \& Thapper L 1990 Nicotine and cotinine concentrations in the nursing mother and her infant. Acta Paediatrica Scandinavica 79 142-147.

Davis WK, Benito CA, Harraid HJ \& Welman JP 2005 Plasma corticosterone in the rat in response to nicotine and saline injections in a context previously paired or unpaired with nicotine. Psychopharmacology 180 466-472.

Dewey KG 1998 Maternal body composition, caloric restriction and exercise during lactation. Journal of Nutrition 128 379S-380S.

DiFranza JR \& Lew RA 1995 Effect of maternal cigarette smoking on pregnancy complications and sudden infant death syndrome. Journal of Family Practice 40 385-394. 
Divers WA, Wilkes MM, Babaknia A \& Yen SS 1981 Maternal smoking and elevation of catecholamines and metabolites in the amniotic fluid. American Journal of Obstetrics and Gynaecology 141 625-628.

Doumas BT, Watson WA \& Biggs HG 1971 Albumin standards and the measurement of serum albumin with bromcresol green. Clinica Chimica Acta 31 87-96.

Drummond GB 2009 Reporting ethical matters in The Journal of Physiology: standards and advice. Journal of Physiology 587 713-719.

Fagundes AT, Moura EG, Passos MCF, Oliveira E, Toste FP, Bonomo IT, Trevenzoli IH, Garcia RMG \& Lisboa PC 2007 Maternal low-protein diet during lactation programmes body composition and glucose homeostasis in the adult rat offspring. British Journal of Nutrition 98 922-928.

Fagundes AT, Moura EG, Passos MC, Santos-Silva AP, de Oliveira E, Trevenzoli IH, Casimiro-Lopes G, Nogueira-Neto JF \& Lisboa PC 2009 Temporal evaluation of body composition, glucose homeostasis and lipid profile of male rats programmed by maternal protein restriction during lactation. Hormone and Metabolic Research 41 866-873.

Fraga-Marques MC, Moura EG, Claudio-Neto S, Trevenzoli IH, Toste FP, Passos MC, Lisboa PC \& Manhães AC 2009 Neonatal hyperleptinaemia programmes anxiety-like and novelty seeking behaviours but not memory/learning in adult rats. Hormones and Behavior 55 272-279.

Friedewald WT, Levy RI \& Fredrickson DS 1972 Estimation of the concentration of low-density lipoprotein cholesterol in plasma, without use of the preparative ultracentrifuge. Clinical Chemistry 18 499-502.

Gao YJ, Holloway AC, Zeng ZH, Lim GE, Petrik JJ, Foster WG \& Lee RM 2005 Prenatal exposure to nicotine causes postnatal obesity and alteredperivascular adipose tissue function. Obesity Research 13 687-692.

Giglia R, Binns CW \& Alfonso H 2006 Maternal cigarette smoking and breastfeeding duration. Acta Paediatrica 95 1370-1374.

Golding J, Rogers IS \& Emmett PM 1997 Association between breast feeding, child development and behaviour. Early Human Development 29 S175-S184.

Gómez JM 2007 Serum leptin, insulin-like growth factor-I components and sex-hormone binding globulin. Relationship with sex, age and body composition in healthy population. Protein and Peptide Letters 14 708-711.

Gornall AG, Bardawill CJ \& David MM 1949 Determination of serum proteins by means of the biuret reaction. Journal of Biological Chemistry 177 751-766.

Gossain VV, Sherma NK, Srivastava L, Michelakis AM \& Rovner DR 1986 Hormonal effects of smoking - 11: effects on plasma cortisol, growth hormone and prolactin. American Journal of the Medical Sciences 291 325-327.

Grassi G, Seravalle G, Calhoun DA, Bolla GB, Giannattasio C, Marabini M, Del Bo A \& Mancia G 1994 Mechanisms responsible for sympathetic activation by cigarette smoking in humans. Circulation 90 248-253.

Hannöver W, Thyrian JR, Ebner A, Röske K, Grempler J, Kühl R, Hapke U, Fusch C \& John U 2008 Smoking during pregnancy and postpartum: smoking rates and intention to quit smoking or resume after pregnancy. Journal of Women's Health 17 631-640.

Hansen PA, Han DH, Nolte LA, Chen M \& Holloszy JO 1997 DHEA protects against visceral obesity and muscle insulin resistance in rats fed a high-fat diet. American Journal of Physiology 273 R1704-R1708.

Kapoor D \& Jones TH 2005 Smoking and hormones in health and endocrine disorders. European Journal of Endocrinology 152 491-499.

Khramov VA, Kolomeitseva AS \& Papichev NV 2008 Jaffe color test-based microtechnique for determination of milk lactose. Gigiena $i$ Sanitariia 3 86-87.

La Gamma EF \& Black IB 1989 Transcriptional control of adrenal catecholamine and opiate peptide transmitter genes. Brain Research. Molecular Brain Research 5 17-22.

Li MD, Kane JK, Parker SL, McAllen K, Matta SG \& Sharp BM 2000 Nicotine administration enhances NPY expression in the rat hypothalamus. Brain Research 157164.

Lichtensteiger W, Ribary U, Schlumpf M, Odermatt B \& Widmer HR 1988 Prenatal adverse effects of nicotine on the developing brain. Progress in Brain Research 73 137-157.

Lowry OH, Roseberough NJ \& Sarral Randal RJ 1951 Protein measurement with the Folin phenol reagent. Journal of Biological Chemistry 193 265-275.
Luck W \& Nau H 1987 Nicotine and cotinine concentrations in the milk of smoking mothers: influence of cigarette consumption and diurnal variation. European Journal of Pediatrics 146 21-26.

Maeda K, Noguchi Y \& Fukui T 2003 The effects of cessation from cigarette smoking on the lipid and lipoprotein profiles: a meta-analysis. Preventive Medicine 37 283-290.

Mantzoros CS, Varvarigou A, Kaklamani VG, Beratis NG \& Flier JS 1997 Effect of birth weight and maternal smoking on cord blood leptin concentrations of full-term and preterm newborns. Clinics in Endocrinology and Metabolism 9 2856-2860.

Marques RG, Morales MM \& Petroianu A 2009 Brazilian law for scientific use of animals. Acta Cirúrgica Brasileira 24 69-74.

McBride CM \& Pirie PL 1990 Postpartum smoking relapse. Addictive Behaviors 15 165-168.

Murrin LC, Ferrer JR, Wanyun Z \& Haley NJ 1987 Nicotine administration to rats: methodological considerations. Life Sciences 40 1699-1708.

Narayanan U, Birru S, Vaglenova J \& Breese CR 2002 Nicotinic receptor expression following nicotine exposure via maternal milk. Neuroreport 13 961-963.

Navarro HA, Seidler FJ, Schwartz RD, Baker FE, Dobbins SS \& Slotkin TA 1989 Prenatal exposure to nicotine impairs nervous system development at a dose, which does not affect viability or growth. Brain Research Bulletin 23 187-192.

Nel MR \& Morgan M 1996 Smoking and anaesthesia revisited. Anaesthesia 51 309-311.

O'Campo P, Faden RR, Brown H \& Gielen AC 1992 The impact of pregnancy on women's prenatal and postpartum smoking behavior. American Journal of Preventive Medicine 8 8-13.

Oeser A, Goffaux J, Snead W \& Carlson MG 1999 Plasma leptin concentrations and lipid profiles during nicotine abstinence. American Journal of the Medical Sciences 318 152-157.

Oliveira E, Moura E, Santos-Silva A, Fagundes A, Rios A, Abreu-Villaca Y, Nogueira Neto J, Passos M \& Lisboa P 2009 Short and long-term effects of maternal nicotine exposure during lactation on body adiposity, lipid profile and thyroid function of rat offspring. Journal of Endocrinology 202 397-405.

Pauly JR, Grun EU \& Collins AC 1992 Tolerance to nicotine following chronic treatment by injections: a potential role for corticosterone. Psychopharmacology 108 33-39.

Peterson GL 1977 A simplification of the protein assay method of Lowry et al. which is more generally applicable. Analytical Biochemistry 83 346-356.

Polańska K, Hanke W, Sobala W, Ligocka D \& Lowe J 2006 Environmental tobacco smoke exposure in pregnancy and postpartum period. Przeglad Lekarski 3 907-910.

Quensel M, Soderstrom A, Agardh CD \& Nilsson-Ehle P 1989 High density lipoprotein concentrations after cessation of smoking: the importance of alterations in diet. Atherosclerosis 75 189-193.

Reselandn JE, Mundal HH, Hollung K, Haugen F, Zahid N, Anderssen SA \& Drevon CA 2005 Cigarette smoking may reduce plasma leptin concentration via catecholamines, prostaglandins. Prostaglandins, Leukotrienes, and Essential Fatty Acids 73 43-49.

Robinson AG 1977 Neurophysins and their physiological significance. Hospital Practice 12 57-63.

Roy AF, Benomar Y, Bailleux V, Vacher CM, Aubourg A, Gertler A, Djiane J \& Taouis M 2007 Lack of cross-desensitization between leptin and prolactin signaling pathways despite the induction of suppressor of cytokine signaling 3 and PTP-1B. Journal of Endocrinology 195 341-350.

Sala F, Nistri A \& Criado M 2008 Nicotinic acetylcholine receptors of adrenal chromaffin cells. Acta Physiologica 192 203-212.

Stauffer CE 1975 A linear standard curve for the Folin Lowry determination of protein. Analytical Biochemistry 69 646-648.

Stellman SD \& Djordjevic MV 2009 Monitoring the tobacco use epidemic II: the agent: current and emerging tobacco products. Preventive Medicine 48 S11-S15.

Sterling CR \& Tank AW 2001 Adrenal tyrosine hydroxylase activity and gene expression are increased by intraventricular administration of nicotine. Journal of Pharmacology and Experimental Therapeutics 296 15-21. 
Sun B, Sterling CR \& Tank AW 2003 Chronic nicotine treatment leads to sustained stimulation of tyrosine hydroxylase gene transcription rate in rat adrenal medulla. Journal of Pharmacology and Experimental Therapeutics $304575-588$

Szymeczko R, Kapelański W, Piotrowska A, Dybała J, Bogusławska-Tryk M, Burlikowska K, Hertig I, Sassek M, Pruszyńska-Oszmałek E \& Maćkowiak P 2009 Changes in the content of major proteins and selected hormones in the blood serum of piglets during the early postnatal period. Folia Biologica 57 97-103.

Tank AW, Osterhout CA \& Sterling CR 1998 Regulation of tyrosine hydroxylase activity by muscarinic agonists in rat adrenal medulla. Journal of Pharmacology and Experimental Therapeutics 286 848-854.

Tannenbaum GS, Gurd W \& Lapointe M 1998 Leptin is a potent stimulator of spontaneous pulsatile growth hormone $(\mathrm{GH})$ secretion and the $\mathrm{GH}$ response to GH-releasing hormone. Endocrinology 139 3871-3875.

Thomas GA, Davies SV, Rhodes J, Russell MAH, Feyerabend C \& Sawe U 1995 Is transdermal nicotine associated with cardiovascular risk? Journal of the Royal College of Physicians of London 29 392-396.

Toste FP, de Moura EG, Lisboa PC, Fagundes AT, de Oliveira E \& Passos MC 2006 Neonatal leptin treatment programmes leptin hypothalamic resistance and intermediary metabolic parameters in adult rats. British Journal of Nutrition $95830-837$.

Trauth JA, Seidler FJ \& Slotkin TA 2000 An animal model of adolescent nicotine exposure: effects on gene expression and macromolecular constituents in rat brain regions. Brain Research 867 29-39.

Trevenzoli IH, Valle MMR, Machado FB, Garcia RMG, Passos MCF, Lisboa PC \& Moura EG 2007 Neonatal hyperleptinaemia programmes adrenal medullary function in adult rats: effects on cardiovascular parameters. Journal of Physiology $\mathbf{5 8 0}$ 629-637.
Vinay L, Ben-Mabrouk F, Brocard F, Clarac F, Jean-Xavier C, Pearlstein E \& Pflieger JF 2005 Perinatal development of the motor systems involved in postural control. Neural Plasticity 12 131-139.

Wakade AR \& Wakade TD 1983 Contribution of nicotinic and muscarinic receptors in the secretion of catecholamines evoked by endogenous and exogenous acetylcholine. Neuroscience 10 973-978.

Walker JF, Collins LC, Rowell PP, Goldsmith LJ, Moffatt RJ \& Stamford BA 1999 The effect of smoking on energy expenditure and plasma catecholamine and nicotine levels during light physical activity. Nicotine and Tobacco Research 1 365-370.

Wilkins JN, Carlson HE, Van Vunakis H, Hill MA, Grritz E \& Jarvik ME 1982 Nicotine from cigarette smoking increases circulating levels of cortisol, growth hormone, and prolactin in male chronic smokers. Psychopharmacology 78 305-308.

Wurtman RJ 2002 Stress and the adrenocortical control of epinephrine synthesis. Metabolism 51 (6 Suppl 1) 11-14.

Yeh J \& Barbieri RL 1989 Twenty four h urinary free cortisol in premenopausal cigarette smokers and nonsmokers. Fertility and Sterility 52 1067-1069

Zanardo V, Nicolussi S, Cavallin S, Trevisanuto D, Barbato A, Faggian D, Favaro F \& Plebani M 2005 Effect of maternal smoking on breast milk interleukin-1 $\alpha, \beta$-endorphin, and leptin concentrations. Environmental Health Perspectives 113 1410-1413.

Received in final form 6 February 2010

Accepted 26 February 2010

Made available online as an Accepted Preprint 26 February 2010 